\title{
BOOK REVIEWS / BOEKRESENSIES
}

Wolfgang Schütte, Israels Exil in Juda: Untersuchungen zur Entstehung der Schriftprophetie, OBO, Fribourg: Academic Press Fribourg / Göttingen: Vandenhoeck \& Ruprecht, 2016, 275 pages, hardcover, € 80.00, ISBN 978-3525-53125-9.

Bei dem zu besprechenden Buch handelt es sich um eine Sammlung teils bereits früher publizierter, teils neuer Aufsätze von Wolfgang Schütte, die der Frage nach der Entstehung der Schriftprophetie nachgehen.

Leitend für seine These, die er insbesondere von Hosea und Amos her entfaltet und dann über Micha und Jesaja zu den späteren Propheten weiter verfolgt, ist das Konzept von Israels Exil in Juda, das dem Buch seinen Titel gibt. Gemeint ist damit, dass Flüchtlinge aus dem Nordreich nach der assyrischen Eroberung Israels im 8. Jh. ins Südreich Juda flohen, wo sie ihre israelitische Identität behielten. Texte, die einen exilischen Kontext erkennen lassen, seien darum nicht vorschnell in das babylonische Exil des 6. Jh. zu datieren. Vielmehr sei bei Texten wie Hos 1,2-2,3 immer zuerst zu erwägen, „ob neben der (nach-)babylonischen Zeit auch ein israelitisches Exil in Juda den geistigen Hintergrund des Textes liefern könnte“(S.20). Eine zentrale Frage, der Schütte darum in seinen Aufsätzen nachgeht, ist, welche Grössen jeweils mit Ausdrücken wie „Israel“, „Jakob“, „Josef“, „Ephraim“, aber auch „Juda“ bezeichnet werden.

Der erste Aufsatz mit dem Titel „Wie wurde Juda israelitisiert?“ (zuerst erschienen in $Z A W 124$ [2012] 52-72) ist zugleich eine Auslegeordnung, in der Schütte seine These skizziert. Der Ursprung der Schriftprophetie liegt ihm zufolge in der theologischen Reflexion des Untergangs Israels (S.23f.). Worte des israelitischen Hoseas, die sich im Untergang Israels bewahrheitet hatten, wurden auf judäisches Hoheitsgebiet gerettet und dort zur Verarbeitung der Katastrophe und zur Integration der israelitischen Flüchtlinge tradiert. Mit Hosea und Amos wurde die Schriftprophetie als israelitische Literatur im judäischen Exil geschaffen, die auch kritisches Potential enthielt, um die judäische Politik zu hinterfragen. Israelitische Schreiber waren in Juda begehrte Fachleute und dürften im geistigen Leben des Landes bald Schlüsselrollen besetzt haben, so dass es den israelitischen Schafaniden unter Josia schliesslich gelang, die israelitische Exilstheologie zur staatlichen Anerkennung zu bringen. Das babylonische Exil gab dieser Theologie erneut recht. Während bei Ezechiel immer noch deutlich zwischen Israel und Juda unterschieden wird, wurde die Unterscheidung im 6. Jh. aber zunehmend verwischt und in den Traditionen, die im 7. Jh. eingeführt wurden (u.a. David als einigende Gestalt), in das Ideal eines vereinigten Israels, dem Juda angehört, überführt. 
Nach der Auslegeordnung im ersten Aufsatz folgen weitere Aufsätze, in denen in exegetischer Detailarbeit die skizzierte These dargelegt wird. An Amos, Hosea und Micha möchte Schütte zeigen, dass die Schriftprophetie als israelitische Literatur im Exil in Juda in der Zeitspanne von 722 v.Chr. bis zur Manassezeit entstanden ist (Kapitel 2-6). Während er für Amos und Hosea zeigt, dass das babylonische Exil überhaupt nicht im Blick ist und die Bücher im Wesentlichen im 7. Jh. in ihre Gestalt gekommen sein dürften, rechnet er für das Michabuch mit einer Grundschrift von Mi 1-3 (ohne 2,12f.); 6,1-7,7, die in levitischen Tradentenkreisen entstanden ist, aber erst durch eine perserzeitliche Redaktion (Mi 2,12-13; 4-5; 7,8-20) ihre vorliegende Gestalt bekam. In der Michaschrift sieht Schütte im Unterschied zur Hosea- und Amosschrift also Spuren auch des babylonischen Exils.

Nach Schütte gehört zum Aufkommen der Schriftprophetie auch die Entstehung eines Autorbewusstseins mit Autornamen und Ich-Aussagen, das sich auch in der akkadischen Literatur im 1. Jt. entwickelt (Kapitel 7). Während die Schriftprophetie anfänglich (Hosea, Micha) noch gruppenspezifische levitische Literatur war, beginnt Jesaja die Literatur gegen die politischen Eliten rund um den König zu richten. Amos richtet sich an eine allgemeine Öffentlichkeit und leitet eine nationale Perspektive ein, die dann auch bei Ezechiel zu finden ist (Kapitel 8). Nach Schütte findet im 7. Jh. auch die literarische Konstruktion einer gemeinsamen Vergangenheit Israels und Judas statt: Während in Hosea Aussagen über Juda noch eher additiv eingetragen seien, setze die israelitische Schriftprophetie seit Micha den sozialen Kontext von Juda selbstverständlich voraus. Er schliesst sich damit insbesondere I. Finkelstein an, dass am Ursprung der Israelitisierung Judas die grosse Anzahl von Flüchtlingen steht, die nach 722 nach Juda strömten, während er der These von K. Weingart widerspricht, Juda habe sich schon vor 722 im Sinn der vorstaatlichen Zwölf-Stämme-Überlieferung als „Israel“ verstehen können (Kapitel 9). In Kapitel 10 untersucht Schütte den Gebrauch des Ausdrucks „Ephraim“ in der Schriftprophetie und kommt zum Schluss, dass in Hosea damit noch die für den Untergang Israels verantwortlichen gesellschaftlichen Eliten bezeichnet seien, in der Zeit nach 722 „Ephraim“ das von Jahwe verworfene Israel bezeichne und erst nach 539 „Ephraim“ als einer der zwölf Stämme wieder die Hoffnungsperspektive eines wiederhergestellten Israels teilen könne.

Den babylon-exilischen und nachexilischen Prophetenbücher widmet sich Kapitel 11, wobei Schütte zeigt, dass Jeremia und Ezechiel noch zwischen Israel und Juda unterscheiden, was immer noch eine Koexistenz der beiden Gruppen anzeige. Erst im Verlauf des Babylonischen Exils und dann v.a. mit der Errichtung der persischen Provinz Jehud tritt Juda als eigenständige Grösse neben Israel in den Hintergrund und wird zunehmend als Teil des ZwölfStämme-Israels angeredet. 
Kapitel 12 hat den Charakter eines Resümees, wobei Schütte zur Frage nach dem Ursprung der Schriftprophetie die Position von J. Jeremias, dass die Ablehnung der mündlichen prophetischen Botschaft zur Verschriftlichung des Prophetenwortes geführt habe, der Position von R.G. Kratz, dass die Schriftprophetie als theologische Reflexion schriftgelehrter Kreise auf der Basis älterer Prophetenworte entstanden sei, gegenüberstellt. Schütte's Antwort ist eine Synthese dieser beiden Ansätze. Während gerade für das Hoseabuch eine Tradition des schriftprophetischen Wortes aus erster Hand wahrscheinlich sei, sei doch im Allgemeinen für die Schriftpropheten des 8. Jh. bereits eine schriftgelehrte Sammlung im Sinne von Kratz vorauszusetzen (240).

Die Hauptthese der Studie ist m.E. überzeugend: Die Anfänge der Schriftprophetie sind im Zusammenhang mit dem Untergang des Nordreiches zu sehen und dürften sich in Juda durch (levitische) Tradentenkreise israelitischer Flüchtlinge etabliert haben. Die Beharrlichkeit, mit der Schütte darauf besteht, für Hosea, Amos, Micha und Jesaja zuerst nach einem israelitischen juda-exilischen Hintergrund zu fragen und nicht gleich alles, was nach „Exil“ klingt, ins babylonische Exil zu datieren, ist sehr begrüssenswert und wichtig und stellt eine dringende Anfrage an den gegenwärtigen Trend, auch die Propheten des 8. und frühen 7. Jh. immer später zu datieren. Man muss doch nur Hosea mit einem Sacharja oder Maleachi vergleichen, um zu sehen, dass dazwischen Welten liegen! Auch die Beobachtung, dass noch bis zu Jeremia und Ezechiel Israel und Juda als zwei unterscheidbare Grössen angeredet werden, wobei deutlich wird, dass der gesellschaftliche und politische Einfluss der israelitischen Migranten in Juda beträchtlich war, ist treffend.

Gleichwohl habe ich einige kritische Anfragen an die Studie. Gegen Weingart und das in den alttestamentlichen Texten selbst überlieferte Geschichtsbild, das mit einer Zusammengehörigkeit Israels und Judas von alters her rechnet, folgt Schütte durchgehend Finkelstein, der davon ausgeht, dass die Verbindung zwischen Israel und Juda erst ein literarisches Produkt nach 722 ist. Wenn Schütte allerdings gegen Weingart vorschlägt, dass „Israel“ das von Juda unterschiedene Israel im judäischen Exil sein könnte, „das den Alleinvertretungsanspruch für Israel reklamiert“ (S.168), so stellt sich die Frage, warum Israel überhaupt einen Alleinvertretungsanspruch für „Israel“ reklamieren sollte, wenn es von Seiten Judas keinerlei Regungen gibt, „Israel“ für sich zu beanspruchen. Nach Schütte ist noch bei Jeremia „mein Volk“ ein Ehrentitel Jahwes für Israel, in den Juda nicht eingeschlossen ist (S.195). Um die Ethnie „Juda“ religiös in den Glauben Israels zu integrieren, ohne Israel diesen Ehrentitel abzusprechen, schaffe Jeremia eigens die Formulierung „mir zum Volk“, in die auch Juda und Jerusalem mit einbezogen werden könne: „So schafft es Jer erstmals in der Schriftprophetie, Juda neben Israel eine religiöse Würdigung durch den Gott Israels zukommen zu lassen“ (S.202). Das wirft natürlich sowohl die historische wie auch die religiöse Frage nach der Identität 
Judas in der Zeit vor 722 auf. Schütte beruft sich von Anfang an (S.7) durchgehend fast ausschliesslich auf Finkelstein für die archäologische Bestätigung, dass ein davidisches „Grossisrael“ eine reine spätere Fiktion sei. Doch ist Finkelsteins Position in dieser Frage alles andere als Konsens (Finkelstein hat dazu eine rege Diskussion mit A. Mazar geführt). Wie schon J. Tigay gezeigt hat (You Shall Have No Other Gods: Israelite Religion in the Light of Hebrew Inscriptions, 1986), finden sich in hebräischen Inschriften im Unterschied zum restlichen Kanaan schon in der Zeit der frühen Monarchie praktisch keine anderen theophoren Elemente in Personennahmen als Jahwe und El. Und A. Faust (,The Archaeology of the Israelite Cult: Questioning the Consensus“, BASOR 360, 2010) hat darauf hingewiesen, dass sich Israel und Juda auch in Bezug auf archäologisch auffindbare Heiligtümer für die ganze Königszeit von den übrigen Völkern unterscheidet. Ist es da historisch wirklich plausibel, dass Juda erst ab dem 7. Jh. Anteil an der religiösen Identität Israels als Volk Jahwes bekommen hat? Dazu kommt natürlich noch die ganze Diskussion um die Herkunft Jahwes aus dem Süden, aber auch die Frage nach der Kenntnis pentateuchischer Traditionen in den frühen Schriftpropheten. Wenn beispielsweise Schütte in Hos 6,11 die Verbindung der „Wende des Geschicks meines Volkes“ mit der „Ernte für Juda“ als sekundär ausschliessen möchte, so übersieht er, dass die „Ernte für Juda“ fester Bestandteil einer Reihe von Anspielungen auf Genesistexte ist (siehe W. Gisin, „Adam, Eva und die Jakobsfamilie in Hos 6,7-11a“, 2011) und sich nicht einfach aus dem Text herausbrechen lässt.

Überhaupt, und dies ist eine zweite Anfrage, ist das Problem der Zirkelschlüssigkeit bei redaktionskritischen Entscheidungen nicht gelöst. Stellt man zuerst das Modell auf und nimmt dieses dann als Massstab, um mittels redaktionskritischer Operationen die Texte in die entsprechende Gestalt zu bringen, oder sollte nicht vielmehr Literar- und Redaktionskritik dem Modell vorausgehen? Wenn beispielsweise die positive Erwähnung Ephraims dazu dient, Texte nach-babylon-exilisch zu datieren (z.B. Jes 11; Jer 31), dann können diese Texte nicht gleichzeitig beweisen, dass es vor dem babylonischen Exil in den Schriftpropheten keine positive Erwähnung Ephraims gibt.

Eine dritte, kleinere Anfrage, die sich an verschiedenen Orten ergeben hat (z.B. im Kapitel über die perserzeitliche Redaktion der Michaschrift), ist, welche Spur eigentlich die weitgehende assyrische Eroberung Judas 702 (nach 2 Kön 18,13 werden bis auf Jerusalem alle befestigten Städte Judas eingenommen; laut dem Sanherib-Prisma sind es 46 befestigte Städte und 200‘150 Deportierte) in den frühen Schriftpropheten hinterlässt? Müsste nicht auch dieses Ereignis, ähnlich wie der Untergang des Nordreichs, stärker bedacht werden, bevor Texte vermeintlich eindeutig in Zusammenhang mit dem babylonischen Exil gebracht werden? 
Ich bin also nicht in allen Punkten vom Modell, das Wolfgang Schütte in einer beeindruckenden Gesamtschau darlegt, überzeugt. Doch die Hauptthese, dass nämlich die Schriftprophetie ihren Anfang als israelitische Exilliteratur in Juda im 8./7. Jh. nimmt, überzeugt und macht dieses Buch zu einem äusserst wichtigen Kontrastpunkt zur Tendenz, alles, was in alttestamentlicher Literatur mit einer Krise zu tun hat, ins babylonische Exil zu datieren und gerade Hosea und Amos immer später anzusetzen. Dieser Studie ist eine breite Rezeption und Diskussion zu wünschen.

Benjamin Kilchör, Staatsunabhängige Theologische Hochschule Basel (Switzerland) and Dept. of Ancient Languages, University of Pretoria (South Africa), Grüenaustrasse 21, CH-8624 Grüt (Switzerland). Email: benjamin.kilchoer@sthbasel.ch. Doi: Dttps://doi.org/10.17159/2312$\underline{\text { 3621/2017/v30n3a19 }}$

William S. Morrow. An Introduction to Biblical Law. Grand Rapids: Eerdmans, 2017. 270 pages, soft cover, \$17.82. ISBN 978-0-08028-6865-7.

In the preface (pp. xii-xiii), the author describes this book as the "distillation" of a career of teaching the Old Testament to theology students who would eventually enter the ministry in their different churches. His intended audience includes not only theology students, but also lay people. The author also expresses his indebtedness to the SBL and especially their "Biblical Law Section". The strength of this books lies in the ability of the author to navigate between using the Old Testament as a tool in ministry and engaging in a critical study of the text in academia. The author succeeds, in my view, in presenting something which will be digestible for ministers and lay, but also something with academic depth.

The book is divided into five parts. Part I consists of Chapters 1 to 4 , which serves as an introduction to the broader issues in the interpretation of biblical law. Chapter 1 explains the image on the cover of the book taken from Exodus 17 showing Moses striking a rock and water then flowing from that rock. This image becomes a metaphor of what Morrow wants to accomplish with his book, namely to make a case for the live-giving qualities of Torah. In the rest of this introductory part, Morrow sums up debates about the dates and origins of biblical law in Chapter 2. Chapter 3 addresses the issue of Moses, namely whether he is a historical or metaphorical figure, and Chapter 4 introduces the reader to some modern-day approaches to biblical law, including the use of contemporary legal theories or comparative studies of Ancient Near Eastern material, amongst others.

One important (and slightly disappointing) observation is made at the end of Chapter 2 (p. 22), namely that Morrow prefers to turn his back on Well- 
hausen's basic idea of a “consolidation of Israel's religion” in the exilic and postexilic period. Morrow's main reason for this is the anti-Semitic implications of Wellhausen's construction, but this stance can be considered as a classic example of throwing out the baby with the bathwater, which by default pushes him towards the Kaufmann School. Morrow's standpoint also explains the order in which he discusses the three legal codes. Part III, entitled "Israel in the village assembly" is about the Covenant Code, which makes sense, since it is usually regarded as the oldest legal code in the Pentateuch. Yet "Priestly and Holiness Law" called "Israel in the courts of the Lord" is discussed in Part IV, before Deuteronomy features in Part V under the title of "Israel in the city". This order is the same diachronic order posited by Kaufmann. One might respond to this interpretation by pointing out that it is also the canonical order, but Morrow discusses the Decalogues before the other law codes in Part II. He does offer an explanation of this order by referring to "four different social contexts" (p. 12), three of which he gleaned from Douglas Knight, but it is (at least initially) not clear why the laws are discussed in this order.

In each of the remaining four sections, his discussion usually begins with a general introduction of the most critical issues debated by scholars. Thus, in Part II the first chapter (Chapter 5) on the Decalogue, he introduces the reader to its "organization," its “purpose,” and its “origins”. The next chapter focuses on the second commandment. This pattern is followed throughout the other three parts, with an introduction followed by more detailed discussions of selected topics. In Part III, on the Covenant Code, issues such as "restoration and revenge" in the light of the laws such as the lex talionis, as well as "the Bible and slavery" are discussed. Each of parts two to four is concluded with a list for further reading for the eager student. Furthermore, every single chapter is concluded with a section called "developments," which I found fascinating. In these sections, the development of previously discussed ideas is traced through later periods, including later rabbinic teaching and obviously the New Testament and the early church.

Another aspect that I found fascinating and refreshing is that Part IV, which discusses Priestly laws, and which extends over 80 pages. This in itself does not say much, but when compared to Part V on Deuteronomy, which consists of only 50 pages, it is clear that more effort is directed towards Leviticus than towards Deuteronomy; usually the opposite trend is found in introductions to the Old Testament or the Pentateuch. His discussion of "Priestly and Holiness Law" consists of eight chapters. Chapter 10 is a general introduction to priestly texts, where the issue of the diachronic relationship between $\mathrm{P}$ and $\mathrm{D}$ is also addressed. Morrow opts for a model where $\mathrm{D}$ and $\mathrm{H}$ "developed in dialogue with each other” (p. 115). In terms of historical context, Morrow acknowledges that "writers using the P style played a substantial role in editing the Pentateuch in the postexilic period" (p. 113), but he still argues that some laws, in the H style were written in the late pre-exilic period and that the same scribes who wrote $\mathrm{H}$ 
compiled and edited P laws. In terms of dating, Morrow is thus fairly close to the Kaufmann School and draws extensively on the work of Milgrom and Knohl. Chapter 11 deals with the Tabernacle Laws in the second half of Exodus. Chapter 12 focuses on sacrifice and especially Leviticus 1-10. "Gift offerings" are discussed in Chapter 13. In the latter two chapters, the reader is introduced to wider debates on ritual, the functioning of sacrifices and gift offerings, and at the end of Chapter 13 we find the now familiar "developments" section. Morrow shows how ideas of sacrifice developed in Philo and Josephus, and even later with Paul and the book of Romans. Chapter 14 continues the discussion on the expiatory role of sacrifices and Priestly views on sin. Chapter 15 engages with Leviticus 11-15 and issues around food, death, sex, birth and purity. The last two chapters of Part IV discuss the Holiness Code, especially Leviticus 18-20 and the Jubilee in Leviticus 25. In short, Morrow presents a well-informed but also highly accessible (for the not-so-specialised reader) discussion of Priestly and post-Priestly theology. The reader, whether an undergraduate student or a layperson interested in the Old Testament, will have acquired a very sound foundation from which to explore more specialised topics.

The same can also be said of Part V on Deuteronomy. Five chapters are presented on Deuteronomy. Chapter 18 introduces the reader to the most important issues of the structure of the book and its historical date. Although Morrow presents the arguments around the Urdeuteronomium, he seems reluctant to follow the traditional De Wette argument of linking the text to Josiah's reform. He also provides the reader with an overview of the influence of Ancient Near Eastern law codes such as those of the Hittite Empire and, more importantly, the Neo-Assyrian codes. Chapter 19 engages with covenant theology and issues of religious tolerance, especially in the light of texts such as Deuteronomy 7 and its not so positive view of the Canaanites. In the last section of this chapter, Morrow is quite frank about the positive and negative value of this kind of theology. The issue of cult centralisation is the focus of Chapter 20. Now it becomes clearer why Morrow is reluctant to link the Urdeuteronomium to Josiah's reforms. He would rather understand this text as a "utopian program whose agenda was never fully realized during the monarchical period” (p. 223). Chapter 21 describes the ancient legal system of Deuteronomy and lastly Chapter 22 addresses the issue of the "limits of social solidarity" as found in the book of Deuteronomy. Here, the place of women is discussed and Morrow presents a very honest portrayal of Deuteronomy’s shortcomings in this regard.

In my view, this book is a valuable resource for teachers of the Pentateuch in the future, despite some critical ideas mooted above about dating. Morrow succeeds in presenting the "life-giving" potential of the Torah.

Esias E. Meyer, Department of Old Testament Studies, Faculty of Theology, University of Pretoria, Hatfield, 0028. Email: Sias.meyer@up.ac.za. Doi: https://doi.org/10.17159/2312-3621/2017/v30n3a19 
Jonathan Moo and Robin Routledge, eds. As Long as the Earth Endures: The Bible, Creation and the Environment. Nottingham: Apollos/IVP, 2014. 216 pp., paperback. ISBN 978-1-78359-038-4. 20 GBP.

The essays in this collection have their origin at the triennial conference of the British Tyndale Fellowship held in England in July 2012. Their aim is to offer

biblical, theological and scientific perspectives on creation and the environment, in the hope what we may learn to see the world more clearly, to perceive its beauty and brokenness when and where we ought, and to reflect God's love and wisdom in how we relate to all he has made (cover).

In the "Introduction" (13-31), Jonathan Moo and Robin Routledge raise some general issues regarding Christian perceptions of creation (13-19) and introduce the following essays (19-31). The first essay, by Alister McGrath, "The Doctrine of Creation: Some Theological Reflections" (32-49), surveys Christian positions regarding the creation. They include the doctrine of creation and "natural theology," creation as event and as process, the place of humanity within creation (should it not rather be humanity as creation?), the doctrine of creation and the Trinity and the doctrine of creation in various cultural contexts (including an analysis of why the profile of the doctrine of creation has risen within the last few decades within evangelicalism). Further reflections on different cultural contexts would have been helpful. Why is the doctrine of creation understood and articulated differently on different continents and societies? To what extent does the experience of nature and of humanity's role in it impact on such articulations and actions? Here I focus on the five essays that are devoted to the OT.

In his essay “'In the Beginning It Was Very Good': Genesis 1-2 and the Environment” (50-69), David L. Baker argues that the material on creation and environment in Gen 1-2 can be grouped under four main topics: the affirmation of biodiversity, the dominion of humanity, the provision of food, and the privilege and task of agriculture. Baker studies each topic in quite some detail and offers reflections. Since there are parallels in Gen 1 between the ruling of the sun and the moon and the ruling of people over all the other creatures, Baker argues for an understanding of human dominion over the animal world parallel to the rule of the heavenly lights over day and night.

It is presumably not meant in terms of literal rule, as of a king over his subjects, but perhaps indicates the keeping of order and being the dominant bodies in the sky and on the earth respectively (57).

Robin Routledge ("Cursing and Chaos: The Impact of Human Sin on Creation and the Environment in the Old Testament," 70-91) suggests that there is a close association between the divine curse of the ground and chaos: a key factor in the disjunction of the created order through the fall is the presence 
of chaos. The cursing of the ground is not only the punishment for sin, but also represents a frustration of the divine purpose in creation: "As such its impact may be seen to extend beyond increased difficulties in agriculture to include natural disasters more generally" (91). This association reinforces the promise of future restoration, following the curse and its effects. Linking the return to the chaos motif with cursing the ground suggests that returning chaos may not only be evident in major acts of divine judgement - such as the Flood and the exile - but also has an impact on everyday life. People are called to seek to limit the disorder caused by chaos: "The task of subduing the earth may have become more difficult - but the challenge to human beings to seek to bring order into the present chaos remains" (91).

According to Jamie A. Grant's study of “Creation and Kingship: Environment and Witness in the Yahweh malak Psalms” (92-106), creation reflects the glory of the creator. Therefore,

if the power, might, goodness and righteousness of God are displayed in the created realm, then anything that damages the natural environment in some way tarnishes not the glory of God itself but humanity's ability to perceive the worth and glory of God (105).

In these psalms, the mighty works of God in creation are assumed to speak convincingly even against an unreceptive, sceptical backdrop. The natural environment seems to be a natural bridge between the biblical construct of reality and the sceptical world views of today. In these psalms, the natural world sings the praise of God. The gentiles are invited to join a worshipping community in the praise of the Creator God.

There is a strong sense of wonder in the Yahweh-malak collection wonder at creation, wonder regarding redemption, wonder with regard to acceptance by the God who reigns, wonder in response to the ideas of community belonging and the divine presence (105).

These psalms constitute a dynamic construct of a God who triumphed over primordial chaos in order to bring order, beauty, justice, community and song.

David G. Firth's essay, "The Spirit and the Renewal of Creation: An Old Testament Perspective” (107-124) argues for the significance of the Spirit in creation and in the sustenance of creation as seen in Pss 33:6, 147:18, and 104:29-30. The Spirit also plays a pivotal role in the renewal of creation in Isa 32:15-20 and 34:9-17. Based on this strong association between the Spirit and creation, the Spirit is understood as providing continued hope for all the created order.

In doing so, the three psalms all offer hope that even challenging situations within creation can be faced because of the involvement of 
the Spirit, an involvement that is associated with Yahweh's word (123).

In the Isaiah passages, the Spirit is both the means for initiating a renewal of creation as a vital step in the establishment of justice and also in providing for animals in a context where humans are excluded.

Creation is not something that has necessarily ended in the past but rather is a continued sphere of Yahweh's work, and thus is precisely where we might expect to find his Spirit bringing about renewal and justice (124).

Paul Williamson addresses "Destruction or Transformation? Earth's Future in Biblical Perspective” (125-145). He examines the place of the earth in the biblical metanarrative and offers an analysis of biblical texts regarding the future of the earth. They include depictions of global or cosmic catastrophe that, prima facie, imply radical discontinuity between this world and the next. Williamson concludes that scriptural testimony is ambiguous. At least two different emphases are discernible: "one that stresses stability, permanence and continuity; another that emphasises vulnerability, transience and discontinuity” (144). As this diversity is reflected not only across the testaments, but within individual books and corpora, the biblical authors or editors probably did not consider these diverse ideas as irreconcilable or mutually exclusive. Thus,

... while the present world will one day 'pass away', whatever this entails, it certainly does not mean that our planet will be annihilated or cease to exist. Rather, there will be significant material continuity between the present cosmos and the new creation (144f).

The remaining essays address the theme from the perspective of the NT and systematic theology: Jonathan Moo, "New Testament Hope and a Christian Environmental Ethos" (146-168); Sean McDonough, "Paradise by the Desolation Trail: De-Creation and the New Testament” (169-185); David Rainey, "Jürgen Moltmann: Creation and the Restructuring of Trinitarian Panentheism" (186-202); Graham J. Watts, “On Being Green Without Playing God: Colin Gunton’s Environmental Ethic” (203-216) and R. J. Berry, "Does Disputing Evolution Discourage Creation Care?” (217-238). The volume closes with reflections by the late I. Howard Marshall on "Ethical Decision-Making” (239249) and an index of Scripture references (250-256).

The volume offers valuable insights from a distinctly Christian perspective. The authors attempt to combine the study of biblical texts with serious interaction with present-day challenges regarding the environment and its sad state. They offer several fresh perspectives. A number of issues are, however, not explored in a satisfactory manner. One might have included an essay on creation in early Judaism. The reception history of biblical texts regarding creation and its maintenance by God and people is not explored. Likewise, the very 
different contexts and perceptions of creation in biblical times (for all its beauty, nature and its catastrophes are also seen as a threat to human existence) and today (while its threat remains for some peoples and parts of the world, nature is seen as fragile and in need of protection from and by humans; so at least the dominant Western perception) are not addressed or reflected upon in any depth. What does it mean to read the biblical texts and to articulate a Christian doctrine of creation under these very different circumstances? Some of the conclusions regarding the pressing issues of today are very modest, perhaps due to British understatement. While the essays on the Bible in this volume focus on creation issues in biblical texts and less on ecological readings and hermeneutics of biblical texts, the volume still has the potential to contribute to the projects and quests of the current ecology group of the OTSSA.

Prof Dr Christoph Stenschke, Dozent der Biblisch-Theologischen Akademie, Forum Wiedenest, Eichendorffstr. 2, 51702 Bergneustadt, Germany, Professor extraordinarius am Department of Ancient and Biblical Studies, University of South Africa (Pretoria), privat: Bahnhofstrasse 1, 51702 Bergneustadt, Germany, Tel. 0049 (0) 2261 - 9145 85. E-mail: Stenschke@wiedenest.de. Doi: https://doi.org/10.17159/2312-3621/2017/v30n3a19

James, Joshua T. The Storied Ethics of the Thanksgiving Psalms, LHBOTS 658, London - New York, NY: Bloomsbury T\&T Clark, 2017. 161 Pages. Hardcover. ISBN 978-0-5676-7521-7.

Bei der vorliegenden Studie handelt es sich um eine unter der Leitung von John Goldingay geschriebene Dissertation, mit der J.T. James (J.) am Fuller Theological Seminary (Pasadena, CA, USA) promoviert wurde (PhD).

Sie enthält fünf Kapitel: Zunächst wird das Lesen von (Dank-)Psalmen unter ethischer Perspektive vorgestellt. Solche Sichtweisen sind in der jüngeren Zeit auf zunehmendes Interesse gestossen (vgl. u.a. Publikationen von G. Wenham). Einen diesbezüglich noch unterentwickelten Aspekt greift vorliegende Monographie auf, nämlich ,the ethical value of story and storytelling in Israel's thanksgiving psalms“ (3) Die im Buch entwickelte These lautet,

that the storied retellings of the worshipper's (and/or community's) experience of divine deliverance in the thanksgiving psalms greatly contribute to the ethical framework or ethos of the ancient Israelite worshipping community (4).

Dazu werden drei Dankpsalmen $(116 ; 118 ; 138)$ ausgewählt und unter zwei Fragerichtungen bearbeitet: 1. Auf welche Weise wird durch das Erzählen der Erfahrung göttlicher Rettung (,story“) die Hörerschaft ethisch geformt und umgestaltet? 2. Welches ethische Modell wird durch das öffentliche Bezeugen (,storytelling“) in Hinsicht auf das Hören und teilweise Partizipieren der 
Gottesdienstgemeinschaft präfiguriert? J. grenzt sich dabei von einem panethischen Ansatz ab, insofern er nicht der Meinung ist, dass jede gute Liturgie ethische Implikationen mit sich führt: „Good liturgy does not necessarily create or form good people.“ (7) Im zweiten Kapitel wird der in der Theologie entwickelte „narrative ethical approach“ näher vorgestellt (u.a. A. MacIntyre, S. Hauerwas). Es handelt sich weniger um eine neue (exegetische) Methodik als um den Einbezug einer bestimmten Sichtweise: der Wahrnehmung der in den Texten liegenden Möglichkeit, die Zuhörerschaft wertemässig zu prägen. Anders als bei direkt adressierten Geboten, Verboten und Aufforderungen ist von einer impliziten, indirekten, aber möglicherweise ebenso wirkungsvollen ethischen Adressierung und Beeinflussung die Rede. In einen derartigen, narrativ-ethischen Ansatz wurden nicht-narrative Texte wie die der Psalmen bisher kaum einbezogen; sie finden erst seit kurzem Beachtung (vgl. C.J.H. Wright, P. McMillon). Das Gesagte wird beispielhaft am Toda-Psalm 30 dargestellt: Mit seinem Rettungszeugnis lädt der Beter die Gemeinschaft ein, ihr Leben als ein Leben der Dankbarkeit und des Lobpreises zu gestalten, im Sinn von: „what happened to me, it could happen to you too“ (25). Die in der Toda-Gattung inhärenten Betonungen von Spiritualität und gottesdienstlicher Anbetung („worship“) sind Parameter der ethischen (Trans-)Formierung der hörenden und mitbeteiligten Gemeinschaft und haben einen didaktischen Impetus.

In den Kapiteln 3-5, dem Hauptteil des Buches, wird je einer der drei genannten Psalmen unter dem vorgestellten Gesichtspunkt behandelt. J. bietet jeweils den übersetzten Psalmtext dar, behandelt kurz textkritische und linguistische Phänomene und äussert sich danach zu Struktur und Gattung des Psalms. Der Hauptteil besteht in der Interpretation des jeweiligen Psalms entlang seiner Abschnitte, unter besonderer Herausstellung der ethischen Implikationen, die am Schluss zusammengefasst werden. Für die Inhalte im Einzelnen ist auf die Ausführungen zu verweisen. Was Ps 116 betrifft, sieht J. eine Reihe wichtiger Aspekte des Ethos der altisraelitischen Gottesdienstgemeinschaft expliziert: „prayer, sacrifice, thanksgiving, love/commitment, trust, hopefulness, expectancy, and gratitude“ (74). In Ps 118 zeigt sich, dass die berichteten Erfahrungen didaktische, ja exemplarische Momente beinhalten; der Psalm bietet „an ethos of possibility“ (116), welches das Erlösungswerk JHWHs als anhaltend, weitergehend verstehen lässt. Ps 138 hat gegenüber den andern beiden Psalmen einen universalen Horizont.

Yahweh's involvement in the life of this individual should become a paradigm for what might be, and as such, it should lead to an expectation of similar redemptive activity in diverse situations. Their story should lead to hope. (142).

Eine kurze Zusammenfassung beschliesst den Band. Beigegeben sind Bibliographie und zwei Indices (Stellen, Autoren). 
Die vorliegende Studie zur Betrachtung der Psalmen unter einer (verstärkt) „ethischen“ Leseperspektive ist zu begrüssen und fügt sich gut ein in neuere und neuste Beiträge diesbezüglicher Psalmenforschung. Mit ihrem textpragmatischen Akzent erweist sie sich zudem als relevant im Blick auf die Neuverwendung der Psalmen in Glaubensgemeinschaften und für das persönliche Glaubensleben bis heute. Neben der weisheitlich-didaktisch geprägten Buchgestalt mit ihrer Tora-Struktur (Ps 1, Fünfteilung) sind die Toda- bzw. Thanksgiving-Psalmen, die über die formularische Wiederverwendung hinaus (die freilich für die allermeisten Psalmen gelten dürfte) für eine (verstärkt) „ethische“ Betrachtungsweise gleichsam disponiert. Ein wesentlicher Grund liegt in der dieser Gattung eigenen vertikalhorizontalen Doppeladressierung an Gott (Lobdank) wie an die teilnehmende Gemeinschaft (Bezeugung, Aufrufe etc.). J. gibt in den Einleitungskapiteln hilfreiche Hinweise und Einsichten und trägt bei der Auslegung der drei Psalmen viele gute Beobachtungen zusammen. Allerdings leidet die Arbeit an gewissen Unklarheiten und methodischen Mängeln. Ich greife drei Aspekte heraus:

(i) Terminologie: Ob die Verwendung des Begriff „Ethik“ (und „Ethos“) für den gemeinten Sachverhalt glücklich ist, ist diskutierbar. Die Übertragung von Begrifflichkeit des Hautgenres „Erzählung“ (narrative, story, storytelling, narrative ethics etc.) in die (Psalmen-)Poesie ist jedenfalls unglücklich. Damit wird eine „lineare“ Wahrnehmung übergewichtet und der Rede-Charakter (in den Psalmen wird „berichtet“, nicht „erzählt“) zu wenig wahrgenommen. (Psalmen-)Poesie „funktioniert“ anders als Narration. Entsprechend sind angepasste Verstehensparameter im Rahmen eines „poetic ethical approach“ zu skizzieren.

(ii) Gattung und Setting: J. verwendet den Gattungsbegriff „thanksgiving psalms“ (deutsch: „Danklied [eines Einzelnen]“, hebräisch: tôdâ). Auch wenn zu enge Gattungsdefinitionen nicht hilfreich sind, so ist gerade bei dieser Gattung ein (ritueller) Geschehensablauf recht gut zu erkennen und der Ort der Psalmaufführung darin: die Bezeugung von erfahrener individueller Gottesrettung samt Dank an Gott im Dabeisein einer Gemeinschaft, die sich aus Freunden, Vertrauten und Dazugekommenen zusammensetzt. Es geht um die persönliche Erfahrung („kleine Rettung“), nicht um diejenige des gesamten Gottesvolks (,grosse Rettung“). Entsprechend ist auch nicht die Volksgemeinde zugegen, vielmehr handelt es sich um eine Art familären „Kleingottesdienst“ (die Gattung eines „[kollektiven] Danklieds Israels“ ist strittig und die Abgrenzung zum Hymnus unklar). Bei J. ist die Gattungsverwendung nicht hinreichend klar, insbesondere was die „worshipping community“ betrifft. Ist hier die Kleingemeinschaft der Gattung im Blick oder bereits ganz Israel (und die Kirche)? Ist die Gattungsperspektive verlassen und 
Book Reviews / Boekresensies, OTE 30/3 (2017): 874-887

der Psalm als literarischer, in das Buch eingebetteter Text Ausgangspunkt? Die „Vermischung“ zeigt sich auch in der vorgenommenen Auwahl der Psalmen. Neben dem „klassischen“ Ps 30 als Beispiel und Ps 116 ist die Wahl von Ps 118 und 138 weniger glücklich. Denn die Gattung ist in diesen „vermischten“ Psalmen teils aufgelöst, kollektive und/oder königliche Sprechende werden einbezogen und das Toda-Setting ist aufgesprengt. Warum sind nicht unstrittige Toda-Psalmen gewählt wurden? Weshalb sind alle drei Psalmen aus dem (späten) Teilbuch V entnommen? Bei lediglich drei Psalmen, davon zwei mit diskutabler Gattungszuordnung, ist eine „storied ethics of the thanksgiving psalms“ nicht hinreichend gewährleistet.

(iii) Ethik und Textpragmatik: Auch wenn das Wort von J. vermieden wird, tritt bei (s)einer ethischen Betrachtungsweise die textpragmatische Zugangsweise und Methodik in den Vordergrund. Gerade im Blick auf „ethische“ Momente wäre es angezeigt gewesen, die Reden in den TodaPsalmen kommunikativ zu bestimmen (Sprechakte, Adressierungen etc.). Damit liessen sich über die Rettungsberichte hinaus hilfreiche Differenzierungen und eine Profilierung „ethischer“ Momente gewinnen. So sind z.B. die Rettungsberichte in Ps 30 an Gott gerichtet (Gebet), in Ps 116 hingegen sind diese weithin Teil einer Er-Rede, also Zeugnis gegenüber den Anwesenden, allerdings gibt es solche auch in kurzen, eingelegten Gebeten (V. 8.16). In Ps 30 wird an die Anwesenden direkt appelliert; sie werden zum Mitfeiern aufgerufen und daraufhin wird ihnen eine Belehrung mitgegeben (V. 5f.). In Ps 116 fehlen Aufrufe an die Mitfeiernden, dafür werden - eher ungewöhnlich - zwei kurze Selbstreden (V. 10f.) kundgetan. Was ergibt sich aus diesem Befund im Blick auf eine ethische (Trans-)Formierung der partizipierenden Gemeinschaft?

Insgesamt eine interessante Studie zu einem interessanten Thema mit vielen guten Einsichten, aber fehlender methodischer Klarheit, die der Studie gut getan hätte.

Beat Weber, Basel, Switzerland; Research Associate of the Department of Ancient Languages and Cultures, University of Pretoria, South Africa. E-mail: weber-lehnherr@sunrise.ch.

Doi: https://doi.org/10.17159/2312-3621/2017/v30n3a19 